Portland State University

PDXScholar

$5-24-2019$

\title{
Translation of Personal Narrative from Russian to English
}

Miles J. Strang

Portland State University

Follow this and additional works at: https://pdxscholar.library.pdx.edu/honorstheses Let us know how access to this document benefits you.

\section{Recommended Citation}

Strang, Miles J., "Translation of Personal Narrative from Russian to English" (2019). University Honors Theses. Paper 741.

https://doi.org/10.15760/honors.758

This Thesis is brought to you for free and open access. It has been accepted for inclusion in University Honors Theses by an authorized administrator of PDXScholar. Please contact us if we can make this document more accessible: pdxscholar@pdx.edu. 
Running head: PERSONAL NARRATIVE

Translation of Personal Narrative from Russian to English

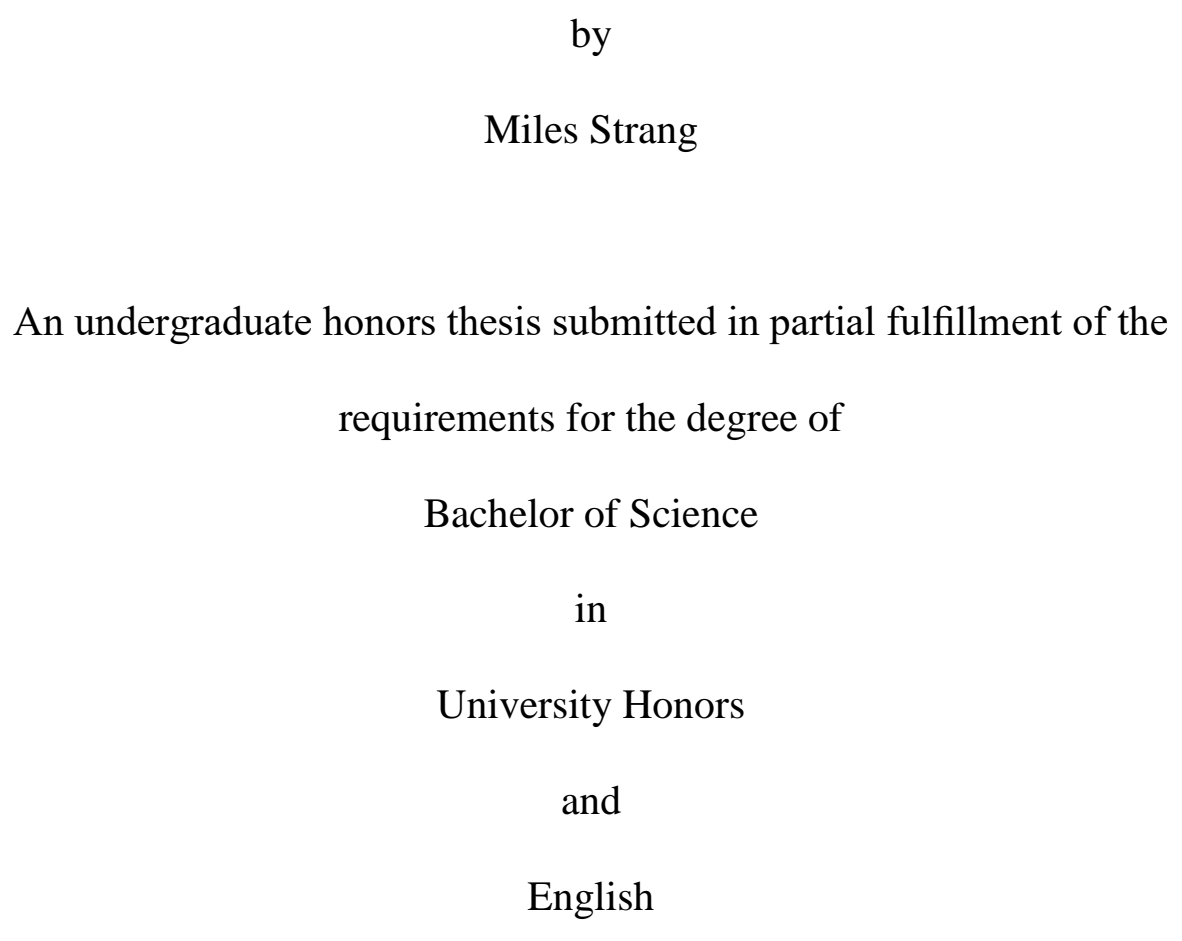

Thesis Adviser

Anna Alsufieva, $\mathrm{PhD}$

Portland State University

2019 


\begin{abstract}
This work is an exercise in basic translation theory. The goal of the work is to explore how translators understand and interpret a text and how they modify it for their audience. The works chosen for this are two short personal narratives from the book The World at First Glance (2012) by Tat'yana Lazareva. These short personal narratives were written by two famous modern Russian personalities: Mikhail Shirvindt, a TV presenter and TV and film producer, and Leonid Parfyonov, a journalist and writer of many documentary TV shows. These are the first translations of these texts in to English. Each text was chosen for specific aspects, such as storytelling elements and the cultural references.
\end{abstract}




\section{Introduction}

One of the best parts of being an English major is the literature. Of course, I love my mother tongue, however, I love the process of reading and unpacking the different layers of an author's work. Similarly, one of the great things about also being a Russian language major is that it opens a whole new world of literature to me. That is why with this thesis, I wanted to challenge myself. How could I combine every aspect of my higher education into one coherent thesis? As a student of both the English and Russian languages, along with a minor in creative writing, it was difficult to do, however, after a lot of thinking, my advisor and I came up with a solution.

We decided to translate two separate short personal narratives from Russian in to English. Doing this would accomplish several tasks. First, it would give me an introduction in to the art of translation. Second, translating from Russian would allow me an opportunity to both test my abilities in and learn more about the Russian language. Third, thanks to the works selected, it gives me a better understanding of Russian culture and society. Lastly, this gives me an opportunity to examine if personal narratives are told in Russian as they are English. In short, this thesis contains several academic disciplines.

As with any project of this magnitude, it was a lot more work than I expected. Initially, I was thinking that the purpose of translation was to preserve the initial text as closely as possible, i.e. word-for-word or a "literal translation." However, as Russian and English are vastly different languages, a literal translation is inadvisable. For example, Russian is a heavily inflected language, in which changing morphemes determine the function of a word in a given sentence. English, on the other hand, heavily relies strict word order rules to accomplish the same thing. This fact alone makes direct, word-for-word translations from Russian to English undesirable, as 
the result would be subpar and difficult to understand. One example of this is with the "У меня есть" construction to show possession ("I have" in English). A literal translation of the sentence “У меня есть яблоко" would roughly translate to "Ву me (у меня) is (есть) apple (яблоко)." Any native English speaker would agree that this translation sounds strange at best, if not nonsensical. Additionally, this sentence shows another difference between the languages, regarding the use of articles. Russian doesn't use definite or indefinite articles as English does, so to an English speaker, the previous sentence would sound grammatically strange and incorrect. There are many other examples of these kinds of linguistic differences which make literal translations between the two languages a poor choice.

Instead, it is up to the translator to use their mastery of each language in order to appropriately modify the text for the desired audience. For example, with the example of "y меня есть яблоко", I would completely change the phrase to the sentence "I have an apple" or "I've got an apple," depending on how colloquial the context is. By adding the indefinite article "an" and changing the "У меня есть" portion to the phrase "I have" or "I've got," an Englishspeaking audience would understand the meaning. In short, translators must figure out what information they can and cannot translate directly, while adding, modifying, and taking away words as they see fit. It is more about translating the idea of what is being said, not how it is being said (although there are aspects of the "how" that should be kept, like narrative structure).

This was the first, among many other hurdles for my translations. One of the other larger aspects were the cultural aspects. As an American-born person with no Russian heritage, from a largely homogenous rural area in California, who has never been to Russia, I had little understanding of a lot of the colloquial expressions and cultural references. My advisor is a native-born Russian and a trained philologist. She helped explain a lot of these, so I could adapt 
them to be understood by an American audience. Of course, occasionally footnotes are needed to explain some things.

Overall, I am happy with the finished products, especially since I have only been seriously studying Russian for about two academic years. Of course, there is room for improvement, but for the sake of this thesis, I am happy. I learned a lot about the translation process, Russian culture, the English and Russian languages, and various narrative writing techniques that apply to both languages. While this was a difficult project, it was well worth it in the end, and I am proud of the work. 


\section{Choosing the Texts}

To meet my lofty expectations for this assignment, my advisor helped me find something that fit the bill. In the end, she found a non-fiction book called Мир с первого взгляда (Татьяна Лезарева, Михаил Нисенбаум), or in English, The World at First Glance by Tat'yana Lazareva and Mikhail Nisenbaum, in which famous Russian personalities wrote about accounts from their childhood.

This book was chosen for a few reasons. First, the individual texts from each person were short and digestible, which are perfect for someone doing their first translation, like myself. Second, the two of the texts were chosen for their specific characteristics. The first text, “Foxfur,” by Mikhail Shirvindt (“Лисмех”, Михаил Ширвиндт) was chosen because of its” storytelling elements. The text "Christmas Decorations,” by Leonid Parfyonov (“Ёлочные игрушки”, Леонид Парфёнов) was chosen mainly because of its heavy use Soviet cultural references and complex literary devices.

Lastly, simply for reasons of personal fulfillment, there is no known translation of this book in to English (that we could find, that is), so we thought it would be fun to be the "trailblazers" of these texts. 


\section{Translation Approach}

I am a big believer in the maxim "keep it simple, stupid." I try to do this with everything, so this was no different. During my literature review, I came across a simple two-step method of decoding and encoding that proved to work well with these personal narratives.

In Kinga Klaudy's book Languages in Translation, when writing about the process of translation, she writes:

"This would mean the process of translation is nothing, but an analysis of the sourcelanguage text followed by a synthesis in the target language, or, in other words, decoding of the source text and encoding of the target text, while there is no direct transcoding from the source-language form to the target-language form" (155).

In short, what she is saying is that translation is more about figuring out what is being said, rather than how it is said. The most important words she uses here (for my purposes) are decoding and encoding.

With decoding, this refers to the process of figuring out what is being said. For me, this was a two-step process. As previously mentioned, I first did a literal, word-for-word translation. After this, I took my literal to my native-Russian speaking advisor to help me decode what was being said.

After this, it was up to me to encode the decoded content in to American English. I chose American English simply because I am a native American English speaker. I had to be sure to keep a few things in mind regarding American English speakers: 
- In general, the native English-speaking population of the world has a poor understanding of Russian culture and society, especially during the Soviet era, so certain things must be explained via footnotes.

- American English is full of slang and idiomatic phrases which are widely used in colloquial speech. It was a challenge to choose which of these (if any) to use.

- Some words in Russian translate better in to British English. For example, “ёлочная игрушка" can translate to "bauble," which is commonly said in British English when referring to Christmas ornaments. Many American English-speakers wouldn’t know what "bauble" means, so that would have to be changed to something that is more understood.

This brings me to the topic of the personal narrative. According to Jacqueline Goodwin's essay Personal Narrative Essays, "A personal narrative essay is a story you choose to share with readers, for it communicates your understanding of yourself, others, and/or society" (2015). For my purposes, the most important aspect of her definition is that personal narratives are stories. This is where I deviated from Klaudy's process of translation. As these are essentially personal stories, which follow a specific sequence of events, it was important to retain said sequence of events.

In summary, the main aspects of my method were as follows:

1. Decode what was being said from Russian

2. Encode the information into American English

3. Keep the narrative structure, as these are stories, with specific sequences of events 


\section{Translated Text: "Foxfur"}

I was seven or eight years old. The Theatre of Satire arrived on tour in Leningrad ${ }^{1}$, and they took me with them, as my father worked for them. As usual, I annoyed everyone-most of all my dad. In order to get away, he gave me two rubles and left to go on a walk. I left too. Straight ahead of me, near the theatre, was a toy store. Naturally, the first thing I did was go there. I quickly stopped by and froze: there was this ugly fox staring at me from the counter. I've never seen such beauty in my life! On top of that, it cost exactly two rubles, penny for penny. It was a sign. I immediately bought the fox. It was packed in a box labelled "Fox Fur," so for many years, he was called one word: Foxfur.

Wherever I was, and wherever I was going, I never left without Foxfur; not for a second.

His whiskers immediately fell out (they were connected on both sides: pull on one side and the other will come out). His eyes were little plastic triangles, which also fell off when he was washed.

There were several times when Foxfur got in in trouble, and my fate was hanging by a thread.

The first tragic event happened in $\mathrm{Kiev}^{2}$. I was sitting in a hotel room, so while bored and goofing off, I decided to scare my mom. I tie a thread in the tail, hold the spool in my hand, and say "Mom, look!", and throw the fox out the window. Naturally, the thread broke at that second, and Foxfur became a flying squirrel and fell out the window.

\footnotetext{
${ }^{1}$ St. Petersburg.

${ }^{2}$ Largest city in Ukraine.
} 
Mama didn't even understand what happened. I jumped on the balcony and looked down-Foxfur is lying on the roof of a restaurant. There is no chance to save him. I'm crying a lot, but mom (with good reason) says "You threw it, what are you gonna do about it?"

I took dad's concert shoe and threw it out of the window on the same roof. They yelled at me. The screaming continued as my dad climbed the fire escape to get his shoes. While he was rescuing his shoes, he was forced to help out the fox. Hence, Foxfur was saved for the first time.

After we finished performances, we went on vacation to the Dnieper ${ }^{3}$ river. A pair of newlyweds - Andrei Mironov and Katya Gradova ${ }^{4}$ were there with us.

At the river, I knew, that the life of the fox hung on by a thread and depended on me. Therefore, while laying Foxfur on an inflatable pool floaty, I didn't trust the threads, so I tied him to the floaty with a thick rope. Now, securely tied to the floaty, the fox rocked in the Dnieper waves, relaxing from the previous traumatic experience.

After a while, Andrei approached me and asked to borrow the floaty

- "No, the fox is floating on it." I shrugged.

- "What fox?"

I look, and the floaty is empty. The fox washed away in the Dnieper. I am hysterical, and poor Andrei, who wants to relax on the floaty, instead he dove after the fox for about 40 minutes. Its remarkable: in the end he never found the fox. Foxfur was 30 minutes from where we were. Andrei was chilly, but importantly, the fox was saved once again. Truthfully, the fox caught a cold, as water kept condensing on his nose because of his time in the water.

Foxfur faithfully and truthfully served me for around 20 years. I took him with me on every tour and during every performance; he was my talisman. Even as an adult I kept a superstitious

\footnotetext{
${ }^{3}$ River flowing from Russia to the Black Sea via Belarus and Ukraine.

${ }^{4}$ Famous Soviet actors.
} 
attachment to the fox. Once we went with the company on vacation. The car was old, and I was nervous. When we stopped at a hotel in Kharkov ${ }^{5}$, I noticed that the fox wasn't with me. We rushed to the telegraph, called the hotel in Kharkov, and asked them to send the fox to us on the train. We stayed at the station, waiting in anticipation. The conductor, with puzzled eyes, gave me the fox and probably thought it was full of diamonds.

A whole era passed. After many years, I arrive in St. Petersburg. I was feeling nostalgic, so I stopped at the same store from before. Suddenly, in the stuffed toys area, I see "Foxfur." It was amazing! I thought Foxfur was the only one in the world. In delight, I bought two of the little foxes for my children, so now everyone had a Foxfur. The main Foxfur could not bear this betrayal! He disappeared at that second, soon followed by the other two.

So, he lived a long and happy life: more than two dozen years. That is more than foxes live in the wild!

\footnotetext{
${ }^{5}$ Second-largest city in Ukraine.
} 


\section{"Foxfur" Commentary}

Of the two pieces, "Foxfur" was much easier to translate, however as with anything, there were difficulties. It used simple language, so it was fairly easy to understand, but there a strange aspect to it; namely a few points where the author uses the present tense narrative, or in other words, shifting from past tense to present tense to explain past events. For example, this first occurs when the author writes:

Первая трагическая история произошла в Киеве. Я сидел в гостиничном номере, маялся от безделья и решил слегка пугнуть маму. Привязываю к хвосту лисёнка нитку, катушку держу в руке, говорю: «Мам, смотри!» И выбрасываю лисёнка в окно. Естественно, нитка оборвалась в ту же секунду, и Лисмех упал вниз (Lazareva, 2012, p. 186).

Here, the first two sentence contain the verbs “произошла, сидел, and решил” (happened, sat, and decided, respectively). These are in the past tense, which can be seen via the “-л/a" suffixes. The paragraph then shifts to the present tense, which can be seen with the verbs which are conjugated in the first-person singular (-y/-ю suffixes) for the present tense, such as “(я) привязываю, держу, говорю, and выбрасываю” (I tie, I hold, I say, and I throw, respectively). After that, the last sentence switches back to the past tense, as seen with the verbs “оборвалась and упал” (broke and $f e l l)$ with the “-л” infix and suffix.

What is the purpose of this change in tense? This is a clever storytelling technique. According to Tvtropes.com, when discussing the use of the present tense narrative, they say, "The present tense tends to give a work a sense of urgency and immediacy, and as such is often used to increase tension in the story" (2010). In other words, by switching to the present tense, the author puts the reader more "in the moment". As the action is happening "in the moment," it is much more engaging for the reader. The author wanted to emphasize those specific actions for 
PERSONAL NARRATIVE

the reader, so he used tense shift. This occurs two more times throughout the text for the same purpose. 


\section{Translated Text: "Christmas Decorations"}

In my memory, Christmas decorations shimmer as the brightest- in every sense- subject of childhood. Maybe that is because they are only brought out once a year. Birthdays, as known from the song ${ }^{6}$, are celebrated with the same frequency, but not nearly with the same zeal. With these "New-year" decorations, they are probably treated as such because the decorations don't resemble anything else from the rest of life, and because hanging them is considered a ritual.

Dad was hacking away at a tree (well, sawing it down, of course) by himself, like always. In the nearby forest, he cut three meters off of the top of a hefty tree with a lot of red and green pine cones. My dad, walking on hunting skis, pulled the round, coniferous bush by a rope to the nearest road, where the loot sat tied to a sled. The expedition lasted all day. Now, this incident sounds almost pre-revolutionary, but in the 60 's of the $20^{\text {th }}$ century, in the Vologoda oblast ${ }^{7}$, there were no purchased trees, let along artificial ones.

The "Forest Beauty" (name for Christmas tree from Soviet children's books) occupied half of the only room in our krushchyovka ${ }^{8}$, which was in the city of Cherepovets ${ }^{9}$, a city known for its metallurgy plant. The decorations, which were stuffed with cotton, were laid out upon the table. Every year mom bought several new ones, which were tied to strings. First, there was a meeting. The family looked at the tree and decided where each decoration should go. On top part were golden decorations: two highly-valued, two-eyed owls, which had to be separated on the

\footnotetext{
${ }^{6}$ Reference to the Russian song “Песенка Крокодила Гены," (Crocodile Gena’s Song) which became synonymous with birthday celebrartions. Used like English "Happy birthday" song. Originally the Russian song was written for a cartoon based on the children book "Crocodile Gena and his friends" (1966) by Eduard Uspenskii.

${ }^{7}$ Located in North-Western Russia in the Eastern European Plain, which is largely covered by swamps and coniferous forest. Область $=$ region

${ }^{8}$ khrushchyovka (хрущёвка) - colloquial term for three to five story concrete or brick-walled building built in the early 1960s, under the leadership of Nikita Khrushchev.

${ }^{9}$ Largest city in Vologda oblast.
} 
Christmas tree façade. In the center were two different clocks, showing five-to-twelve. On the top was a pike- a star in out non-party house considered too ideological.

The only Soviet hero- a border guard wearing all green with a red star on his cap, kneeling beside his German shepherd, was hung somewhere on the side of the tree. Having been made before WWII, this decoration embodied the image of the famous private Karatsupa ${ }^{10}$ and his faithful dog. Together they detained almost half of a thousand violators of the sacred borders of our country. People called this composition: "We, Mukhtar and I, don't shit ourselves on the border,"11 which I really didn't like.

My favorite decorations were a series of fruits and vegetables from the book I just read by Giovanni Rodari: Cipolinno, Master Grape, Cherry, Senior Tomato, and Prince Lemon. Sorry, there was no Mr. Pumpkin ${ }^{12}$ - as the author would always say in his speeches with a heavy sigh. I repeated this heavy sigh. For example, when I asked my mom if I could go to the pond, she would say “I told you, you can't! You'll get your feet wet again!”- to which, I would reply with the words "And sighed heavily."

The series was released recently in the $60 \mathrm{~s}$, but the decorations were detailed: every eye, every stitch, the epaulettes and the buckles of the rich, as well as the patches of the poor. Class struggle wasn't very interesting to me; rather, I was more interested in the garden characters that make up their world. On the tree, they had to live in their own little community, looking at each other rather than us. They were mounted upright via clips, we maneuvered them, so the Lemon could see the Tomato.

${ }^{10}$ Nikita Fyodorovich Karatsupa (Никита Фёдорович Карацупа) was a colonel of the border guards. Was a Hero of the Soviet Union. Famous for his well-trained dogs and catching trespassers.

11 A colloquial way to say "not afraid".

12 All of these are characters from the children's book written by Italian author Giovanni Rodari (1920 1980) "The Adventures of Cipollino." Cipollino is an onion character. In the USSR "The Adventures of Cipollino" was a popular and well-known children's book. 
Lanterns, icicles, and striped tops occupied the middle tier. Snowflakes and other ornaments were alternating on the bottom tier. Whimsically falling down, the last two strings of beads were hung up. Cotton was spread among the branches- well, where snow would normally be. Revision continued until the last day the Christmas tree was in the apartment. The branches sank overtime, and the decorations occasionally obscured each other. Sometimes, guests or relatives gave us Christmas toys for the New Year. The ornaments were immediately allocated a place, although everything else had to be moved.

The tree was brought the $25^{\text {th }}$ of December. A pot with water in the middle of the overturned children's table strengthened it. The legs of the table and the ropes connecting them to the trunk of the thick pine were not visible. Every morning, while checking for presents from Ded Moroz, I would climb under the tree to water it as the branches scratched my back. The presents- some heavy, some not, arrived throughout the week. Then there was a break for two weeks, and again I waited for another surprise. The tree-almost without losing needles- stood for a whole month until my birthday (26 January), on which I received birthday gifts as New Years gifts.

Writing to this point, I understand that the way I remember all of it feels as if I caught a sailing fleet, stagecoaches, receiving the addressing of "Sir," and the rank of "Staff Captian"." However, I mainly experienced just the tree from the forest. But now even it is gone too.

13 “Stabs-capitan” (штабс-капитан)- a rank in the Russian Army from 1797-1917. 


\section{"Christmas Decorations" Commentary}

This text was much more difficult to translate than the first text. First, as the author is a journalist by profession, so his writing in Russian is at a much more advanced level than my level of reading comprehension. His use of idiomatic Russian expressions made it difficult to translate. For example, the author uses the phrase “и снова жди," which is an order to "and wait again." Here, the infinitive form of the verb “ждать” (to wait) is put into the imperative form “жди” (wait!), which is accompanied with the conjunction "и" (and) and the adverb "снова" (again). These three words form a structure that emphasis the fact that the author has to wait for a long time. In order to get a complete understanding of what he wrote about, I had to use a dictionary a lot and asked my advisor a lot of questions. I had to revise a few parts multiple times to understand exactly what the author was trying to say.

The second issue I came across deals with the word "igrushki” (игрушки). As with English, Russian has a number of homonyms (words that sound the same and are spelled the same, but have different meanings). For example, in English, here are two of the different meanings of the word "lie," which are pronounced and spelled exactly alike:

- to lie down in a bed;

- to lie to someone by saying an intentionally false statement.

This is also the case with the word "igrushki" in Russian. It can mean either "toys" (as I initially thought) or "decorations." When I initially translated this, I thought the story was about toys, so some of the actions made no sense. However, after my advisor explained that the author was writing about christmas decorations, the story made a lot more sense. 
Another difficult moment was when the author used the made-up compound word “уolkostoyaniye” (ёлкостояние) -- 'christmastreestanding', which required an explanation from my advisor.

Another big issue were the cultural references. This story is chock-full of references to Soviet life and culture. There numerous references to famous Soviet actors, popular children's media, heroes, traditions, and places that were completely unknown to me.

As mentioned before, this text required multiple edits. While "Foxfur" only required two revisions, "Christmas Decorations" required six revisions to the translation. According to Emily Whitman, it is common for some works to need multiple translations. This is said in her paper Literary Narrative Prose and Translation Studies, when she writes:

“Frank's ${ }^{14}$ The Diary of a Young Girl (1952) and Wiesel's ${ }^{15}$ Night (1958) have particularly complex translation histories. Frank's many diaries were edited multiple times for translation. Many references to sexuality and family conflicts were rewritten or eliminated along with anti-German sentiment. Wiesel's Night was translated from a French translation, itself a translation of a much longer Yiddish account" (446).

While "Christmas Decorations" did not have the same political censorship issues as Anne Frank's work, I did find some similarities with the problems facing Night. It felt like translating the colloquial speech and cultural references added several extra editing steps (not nearly to the extent of having to translate from Yiddish to French to English, but it is the same idea).

\footnotetext{
14 Anne Frank

15 Elie Weisel
} 


\section{Conclusion}

This thesis accomplished everything I wanted it to. In the first story, "Foxfur," I was able to see how the author used a shift in verbal tense to help bring the reader more in to the action of the scene, to create a more engaging reading experience. In the second story, "Christmas Decorations," the translation opened a whole new world of cultural knowledge about 1960s Russia and the Soviet Union to me, while also showing some interesting instances of word play by the author.

The second text taught me about the complex nature of translation work. I came in to this a lot more confident than I did on my way out. While the first translation went fairly smoothly, the second translation (“Christmas Decorations”) was extremely difficult. It was above my knowledge of both Soviet culture and Russian language.

While these were difficult to translate, it was a rewarding process. It tested my mastery of both English and Russian, while helping me gain a more intimate understanding of each language.

Lastly, I learned a lot about the personal narrative medium, and how it does not change regardless of what language they are written in. By reading these two narratives, I understand that a personal narrative is meant to be, well, very personal. To me, there are a few important characteristics of them, such as:

- Use of colloquial speech rather than "proper" speech.

- Extensive use of personally important cultural references (like Cipolinno in “Christmas Decorations”).

- Memoirs, which are longer, and more complex, typically consist of a series of events over a person's life. They help the author explain their understanding and 
view of the world, while personal narratives are shorter and are usually about a specific story or experience the author wants to tell. These are more about bringing the reader in to a specific event, and how the author's view of the world changed because of it.

All-in-all, I could not be happier with how this turned out. It was difficult and time consuming, but extremely rewarding. Also, now I get to say that I helped translate something for the first time in history. How cool is that?! 


\section{Appendix A: Original Text in Russian : «Лисмех»}

Мне было лет семь-восемь. Театр сатиры приехал на гастроли в Ленинград, меня взяли с собой. Как обычно, я мешал всем, в первую очередь - папе. Чтобы от меня отвязаться, мне дали два рубля и отправили на прогулку. И я пошёл гулять. Прямо рядом с театром находился игрушечный магазин. Конечно, первым делом я отправился туда. Зашёл и вдруг обомлел: с прилавка на меня смотрел безобразный лисёнок. Такой красоты я в жизни не видел! Между прочим, он стоил ровно два рубля, копейка в копейку. Это тоже был знак. Конечно, я сразу купил лиса. Его упаковали в коробку, на которой было написано «ЛИС MEХ». Многие годы его так и звали, одно слово: Лисмех.

Где бы я ни находился, куда бы ни ехал, я не расставался с ним ни на секунду, хотя был уже здоровый восьмилетний лоб.

У него моментально выпои усы (они были взаимосвязаны: тянешь за один ус, а другой сразу уходит внутрь). Глаза - пластмассовые треугольнички - тоже отваливались, когда его стирали.

Но несколько раз Лисмех попадал в настоящую беду, и моя судьба висела на волоске.

Первая трагическая история произошла в Киеве. Я сидел в гостиничном номере, маялся от безделья и решил слегка пугнуть маму. Привязываю к хвосту лисёнка нитку, катушку держу в руке, говорю: «Мам, смотри!» И выбрасываю лисёнка в окно. Естественно, нитка оборвалась в ту же секунду, и Лисмех упал вниз.

Мама даже не поняла, что произошло. Я выскакиваю на балкон, смотрю вниз лис лежит на крыше ресторана. Шансов спасти его нет. Поднимаю крик, но мама с полным основанием говорит: «Ты же сам его выбросил, что теперь поделать?» Тогда я 


\section{PERSONAL NARRATIVE}

взял папин концертный туфель и скинул его из окна на ту же крышу. Теперь кричали уже на меня. Крик продолжался всё время, пока папа лез по пожарной лестнице за туфлем.

Спасая обувь, он вынужден был выручить и лиса. Так Лисмех был спасен в первый раз.

После гастролей мы поехали отдыхать на Днепр. С нами в компании были Андрей Миронов с Катей Градовой, молодожёны.

Теперь я знал, что жизнь лиса может висеть на волоске и зависит от меня. Поэтому, уложив Лисмеха на надувной матрац, я не стал доверяться непрочным ниткам, а привязал матрац толстой верёвкой. На этом надёжно привязанном матраце лис покачивался в днепровских волнах, отдыхая от пережитых бурь.

Через какое-то время ко мне подошёл Андрей и попросил одолжить ему матрац.

- Нет, на нём лис плавает, - развожу я руками.

- Какой лис?

Смотрю - матрац покачивается пустой. Лиса смыло волной в Днепр. У меня истерика, и бедный Андрей, который собирался отдохнуть на матраце, вместо этого вынужден был минут сорок нырять за лисом. И вот что удивительно: в конце концов он его нашёл. Лисмеха отнесло метров на тридцать от того места, где мы расположились. Андрей был синего цвета, но главное - лис снова был спасён. Правда, у лиса потом долго был насморк, после этого купания на носу постоянно образовывалась какая-то капелька. Лисмех прослужил мне верой и правдой лет двадцать. Я брал его с собой на все гастроли и выступления, это был мой талисман. Даже во взрослом возрасте я сохранил некоторую суеверную привязанность к лисёнку. Как-то мы с компанией поехали отдыхать. Машина была старая, я очень нервничал. Когда мы остановились в Харькове, в гостинице обнаружилось, что лиса со мной нет. Мы рванули на телеграф, заказали звонок. 
Моего лиса повезли на вокзал и отправили в Харьков, где мы в ожидании не трогались с места. Проводница, которая с вытаращенными глазами передавала мне лиса, наверное, решила, что он начинён бриллиантами.

Прошла целая эпоха. И вот, спустя много лет, приезжаю в Ленинград, захожу в тот самый магазин, чтобы поностальгировать. И вдруг вижу в отделе мягкой игрушки - «Лис мех»! Это было удивительно: я ведь был убеждён, что Лисмех на свете только один. В восторге я купил двух лисят своим детям, чтобы у каждого был Лисмех. Главный Лисмех не вынес этого предательства. Он исчез в ту же секунду. А потом исчезли и эти двое.

Итак, он прожил долгую и счастливую жизнь: более двух десятков лет. Больше, чем лисы живут в природе. 


\section{Appendix B: Original Text in Russian: «ёлочные игрушки»}

Самым ярким — во всех смыслах — предметом из детства мерцают в памяти елочные игрушки. Может, оттого, что их доставали только раз в году. Но день рождения, как известно из песенки, случается с той же периодичностью, а его празднование таким талисманом не стало. Наверное, дело в непохожести этих новогодних стекляшек ни на что во всей остальной жизни. И конечно, в ритуале их развешивания.

Елку отец рубил (то есть спиливал, конечно) всегда сам. В недалеком лесу отсекалось метра три от вершины здоровенного дерева - непременно со множеством красновато-зелёных шишек. Этот круглый, как шар, хвойный куст отец, шагая на охотничьих лыжах-снегоступах, тянул за собой на верёвке до ближайшей дороги, где добыча привязывалась к санкам. Экспедиция занимала весь день. Теперь звучит с почти дореволюционным размахом, но в 60-е годы XX века в Вологодской области не бывало ни покупных ёлок, ни тем более искусственных.

"Лесная красавица" (определение советских детских книжек) занимала половину единственной комнаты нашей квартиры-хрущёвки, выделенной Череповецким металлургическим заводом. Игрушки, переложенные ватой, раскладывались на столе. Каждый год мама докупала несколько новых — к ним привязывали ниточки. Сначала шло совещание: поглядывая на елку, семья решала, что куда пойдёт. Наверх — мелкие "золотые". Высоко ценились две лупоглазых совы, только их надо было "развести" по елочному фасаду. В центр помещались тоже двое разных часов, показывающих без пяти двенадцать. На макушку надевалась пика - звезду в нашем беспартийном доме считали чересчур идейной. 
Единственный советский герой — весь-весь зелёный, с красной звездочкой на фуражке пограничник, коленопреклоненный подле своей овчарки,- привешивался где-то сбоку. Ещё довоенная, эта игрушка воплощала образы знаменитого рядового Карацупы и его верного пса - они вместе задержали чуть не полтысячи нарушителей священных рубежей Отчизны. В народе композиция называлась "не ссым с Мухтаром на границе" — и мне совсем не нравилась.

Мои фавориты — серия овощей и фруктов из только что прочитанной книжки Джанни Родари: сам Чиполлино, Мастер Виноградинка, Вишенка, Синьор Помидор и Принц Лимон. Жалко, отсутствовал Кум Тыква - авторскую ремарку ко всем его речам "и тяжело вздохнул" я тогда повторял, слыша любой запрет (Мама, можно я запруду пойду делать? - Сказано же: нельзя, опять ноги промочишь! — "И тяжело вздохнул").

Серию выпустили недавно, уже в 1960-е, но выполнена она тонко: глазки прорисованы, на заплатах бедняков и на пряжках-эполетах богачей обозначен каждый шовчик. Классовая борьба меня не особо занимала, интереснее было, что садовоогородные персонажи составляют свой мир. На ёлке им надлежало жить по соседству и смотреть не на нас, а друг на друга. Фигурки крепились стоймя в прищепках, и их аккуратно поворачивали: вот, так Лимон теперь своего Помидора видит.

Фонарики, сосульки и полосатые волчки занимали средний ярус. Понизу чередовались шары и снежинки. Прихотливо ниспадая, последними вешались две нитки бус. Вату разбрасывали по выпирающим веткам — ну, где обычно снег и лежит. Доработка шла до самого последнего дня ёлкостояния. Ветки со временем проседали, и украшения могли заслонять друг друга. Бывало, гости или родня дарили игрушки на 
Новый год. Новинкам тут же выделялось место, из-за чего вся эскпозиция приходила в движение.

Ёлку привозили числа 25-го декабря. Укрепляли её в кастрюле с водой посредь перевернутого детского столика. Ножки столика и связывающие их со стволом верёвки в густой хвое были не видны. Залезая под царапающие спину ветви, свежую воду я подливал ежеутренне, проверяя, нет ли подарков от Деда Мороза. Презенты — то весомые, то не очень,- тянулись с неделю. Потом перерыв недели две - и снова жди сюрпризов: почти не осыпаясь, ёлка жила у нас месяц, аж до моего дня рождения (26 января), и именинные подарки я доставал как новогодние.

Дописав до сих пор, понимаю — как что это мне вспоминается: будто я застал парусный флот, дилижансы, обращение "сударь" и звание "штабс-капитан". А застал только ёлку из леса. Но теперь-то и её нет. 


\section{References}

Academic Dictionaries and Encyclopedias. (2019). Retrieved from https://dic.academic.ru/

Goodwin, J. (2015). Personal Narrative Essays. Retrieved from http://www.sjsu.edu/writingcenter/handouts/Personal\%20Narrative\%20Essays.pdf

Klaudy, K. (2003). Languages in Translation: Lectures on the Theory, Teaching, and Practice of Translation. Budapest: Scholastia.

Lazareva, T. (2012). Mir s pervovo vzglyada. Moscow: Azbuka-Atticus.

Present Tense Narrative. (2010). Retrieved from https://tvtropes.org/pmwiki/pmwiki.php/Main/PresentTenseNarrative

Wittman, E. O. (2013). Literary narrative prose and translation studies. The Routledge Handbook of Translation Studies (pp. 438-450). Routledge. 